\title{
Cikkismertetés: A rendszertudomány alkalmazása az egészséges táplálkozással kapcsolatos egyenlőtlenségek feltárásához - ismertetés
}

\author{
Article review: Using systems science to understand the determinants \\ of inequities in healthy eating - paper review
}

Ismertető: $\quad$ Krakkó Ágnes $₫$
$\quad$ Nemzeti Népegészségügyi Központ

Ismertetett cikk: Friel et al. Using systems science to understand the determinants of inequities in healthy eating. PLOS ONE 2017.Nov. 12(11): e0188872. https://doi.org/10.1371

Beküldve: $\quad$ 2018. 11. 05.

doi: $\quad$ 10.24365/ef.v59i6.379

Kulcsszavak: rendszerszemlélet; egészségegyenlőtlenségek; egészséges táplálkozás

Keywords: systems science; health inequities; healthy eating

\section{BEVEZETÉS}

A közelmúltban teret nyert rendszerszemléletú gondolkodás ígéretes megközelítésként szolgálhat a nem fertőző betegségek megelőzésére és kezelésére. Ezen terület rendszerszemlélet iránti érdeklődése hátterében az áll, hogy egyre több olyan bizonyíték lát napvilágot, amely rámutat a nem fertőző betegségek többszörös, rendszerszintű és összetett okaira, és amelyek megoldásához mind egyéni, mind társadalmi szinten szükséges beavatkozni. A nem fertőző betegségeknek úgy, mint a kardiovaszkuláris betegségeknek, a 2-es típusú cukorbetegségnek, bizonyos daganatoknak és a csontritkulásnak az egyik fő kockázati tényezője az egészségtelen táplálkozás. A magas és közepes jövedelmű országokban a társadalmilag hátrányos helyzetű emberek nagyobb valószínűséggel étkeznek egészségtelenül, ennek eredményeként nagyobb arányban fordul elő körükben táplálkozással összefüggő betegség. Ezek a táplálkozásegészségügyi kockázatok egyenlőtlenül fordulnak elő a különböző társadalmi csoportokban.
Az étkezéssel kapcsolatos egészségügyi problémák tekintetében a kutatások és irányelvek eddig elsődlegesen az egyén szerepére, ismereteire, preferenciáira és magatartására helyezték a hangsúlyt. Azonban egy új társadalmi-gazdasági koncepció számos olyan táplálkozási szokásokkal és egyenlőtlenséggel kapcsolatos tényezőt azonosított társadalmi szinten, melyek befolyásolják az egyén preferenciáit és magatartását.

Az egyre szélesebb körben elterjedt rendszertudomány a nem fertőző betegségek okait mind egyéni, mind társadalmi szempontból képes egyidejúleg vizsgálni. A rendszertudományon belül egy „komplex adaptív rendszer" olyan elemeknek (pl. alrendszerek, szektorok) és elemek közötti interakcióknak az összessége, melyek dinamikus viselkedést eredményeznek. Az „adaptív” szó ebben az esetben arra utal, hogy a rendszer képes változni, például külső behatások következtében. Fontos kihangsúlyozni, hogy a rendszer egyes elemeinek egyenként történő vizsgálatával nem lehetséges egy jelenség megértése, ahhoz a részek közötti dinamika megfigyelése is alapvető fontosságú. Míg 
az élelmiszerellátó-rendszer, a társadalmi, valamint egyéni tényezők bizonyos aspektusai közötti egyes összefüggéseket már részletesen vizsgálták, addig ezen tényezők közötti kapcsolatokat és az egész rendszer egészséges táplálkozási egyenlőtlenségekre gyakorolt hatását eddig még nem tanulmányozták.

Jelen ausztrál vizsgálat összetett rendszerszintű megközelítést alkalmazva összegzi aktuális ismereteinket arra vonatkozóan, hogy a társadalmi és egyéni szintű tényezők kölcsönhatása hogyan vezet egyenlőtlenségekhez az egészséges táplálkozás területén. A vizsgálat során meghatározásra kerülnek a politikai szempontból releváns tényezők és az ezek közötti kölcsönhatások. Ennek leírására a rendszertudományban bevettnek tekinthető „kollaboratív fogalmi modellezés" (Collaborative conceptual modelling, CCM) módszerét alkalmazták egy komplex adaptív rendszerre jellemző oksági diagram (causal loop diagram) felvázolásához. Ennek segítségével megérthetjük az egész rendszer (továbbiakban $\mathrm{HE}^{2}$ rendszer, a "H", mint healthy (egészséges), az „E ${ }^{2 \prime}$ pedig „equitable” (egyenlö) és "eating" (táplálkozás)) viselkedését, mellyel meghatározhatóak a beavatkozási pontok (leverage points) a táplálkozási egyenlőtlenségek kezelésére. Jelen tanulmányban egy szakpolitikai szereplőkből álló szakértői csoport (döntéshozók, egészségügyi szakemberek és kutatók) által végzett kutatás eredményei kerülnek bemutatásra, amely egy nagyobb, az egészséges táplálkozás egyenlőtlenségeivel kapcsolatos szakpolitikai beavatkozással kapcsolatos kihívásokat vizsgáló kutatás része.

\section{VIZSGÁLATI MÓDSZEREK}

A vizsgálat koordinálását egy központi csoport végezte, akik a vizsgálat tervezéséről, adatgyűjtéséről és elemzéséről népegészségügyi kutatókból és egészségügyi szakemberekből álló nagyobb projekt csoporttal konzultáltak. A központi team szaktudása kiterjedt a rendszertudományra, népegészségügyre, epidemiológiára és a táplálkozástudományra.

A módszer lehetővé tette, hogy a különböző szektorok szakértőinek és egyéb érdekelteknek az egészséges táplálkozás terén tapasztalható egyenlótlenségekkel kapcsolatos ismereteit, és tapasztalatait felhasználják a vizsgálatban és azonosítsák a tényezők közötti kapcsolatokat, visszacsatolási hurkokat (feedback loops) és az esetleges nem várt következményeket. Alább a CCM módszer alapján készített oksági diagram elkészítésének lépéseit mutatjuk be.

\section{Érdekeltek/szakpolitikai szakértők bevonása}

A vizsgálatba a központi csoport tagjain kívül 12 szakértőt vontak be, akiknek szaktudása kiterjedt a népegészségügyre, epidemiológiára, táplálkozástudományra, egészség-gazdaságtanra, társadalmi marketingre és közpolitikára. A tudományterületek sokfélesége elősegítette, hogy minél több perspektívát megjelenítsenek a diagramon arra vonatkozóan, hogy az egészséges táplálkozás egyenlőtlenségeit milyen tényezők befolyásolhatják. A csoportban képviselt nézőpontok azonban nem teljes körúek, mivel bizonyos területeken dolgozókat, például az élelmiszer-kiskereskedőket, gyártókat és -szolgáltatókat nem képviselte szakember a csapatban.

\section{Adatgyűjtés és elemzés}

Az adatgyűjtésre és elemzésre kettő, egyenként három óra hosszú workshop keretében került sor Canberrában, az Ausztrál Nemzeti Egyetemen (2015 május és november). Az első workshopon a résztvevők áttekintést kaptak a vizsgálatról, illetve betekintést az olyan összetett problémák, mint a táplálkozási egyenlőtlenségek rendszertudományos megközelítéséről. Arra kérték a résztvevőket, hogy 1 , vitassák meg az egészséges táplálkozás egyenlőtlenségeiből fakadó problémákat és az azt befolyásoló tényezőket; 2 , dolgozzanak ki egyéni elméleti modelleket (mental model) és kombinált, párosított (pair blended) modelleket, melyek a változók közötti kapcsolatokat és a kapcsolat jellegét prezentálják. A második workshop keretében a résztvevők tovább finomították az első workshopon létrehozott oksági diagramot és újra átvizsgálták a meghatározott tényezőket.

\section{Egyéni elméleti modell}

A résztvevők egyénileg rajzoltak fel egy-egy diagramot az egészséges táplálkozás egyenlőtlenségeit 
befolyásoló tényezőkről. Az egyéni elméleti modell előnye, hogy minden közremúködő saját ötletei és perspektívája érvényesülhet, amely csoportos munkában nem feltétlenül valósult volna meg.

\section{Párosítás}

Az egyéni elméleti modell felrajzolását követően a résztvevőkből párokat képeztek, és megkérték őket, egyesítsék diagramjaikat. Ezután a párosított diagramokat addig kombinálták, míg egyetlen, minden változót tartalmazó diagram maradt. Az első workshopot követően a rendszermodellező egy szoftver segítségével szimulációs modellt készített és létrehozta a kezdeti $\mathrm{HE}^{2}$ oksági diagramot. A változókat csoportosították és föbb alrendszerekbe rendezték. A második workshopra ugyanazokat a szakértôket hívták, hogy áttekintsék és ellenőrizzék az oksági diagramot, hogy minden említett változót rögzítettek-e, illetve pótolják az esetleges hiányosságokat. Feladatuk volt továbbá minden egyes változó polaritásának az ellenőrzése
- a pozitív polaritás azt jelenti, hogy két változó ugyanolyan irányba változik, a negatív pedig arra utal, hogy két tényező változásának iránya ellentétes. A második workshopot követően a központi csapat tovább finomította az oksági diagramot, beleértve a változók elnevezését, irányultságát, polaritását és az alrendszerekbe történő csoportosítást.

\section{EREDMÉNYEK}

A szakértők számos többszintű, egymással kapcsolatban lévő tényezőt azonosítottak, melyek befolyásolhatják az egészséges táplálkozás egyenlőtlenségeit. A résztvevők számos tényezőt jegyeztek fel, mint például az élelmiszerfogyasztói preferenciákat és az élelmiszer-körülményeket, azon belül is az élelmiszerárakat, a háztartások típusait és egyéb más szakpolitikai tényezőt. Az első workshop eredményéből egy részlet látható az 1. ábra.

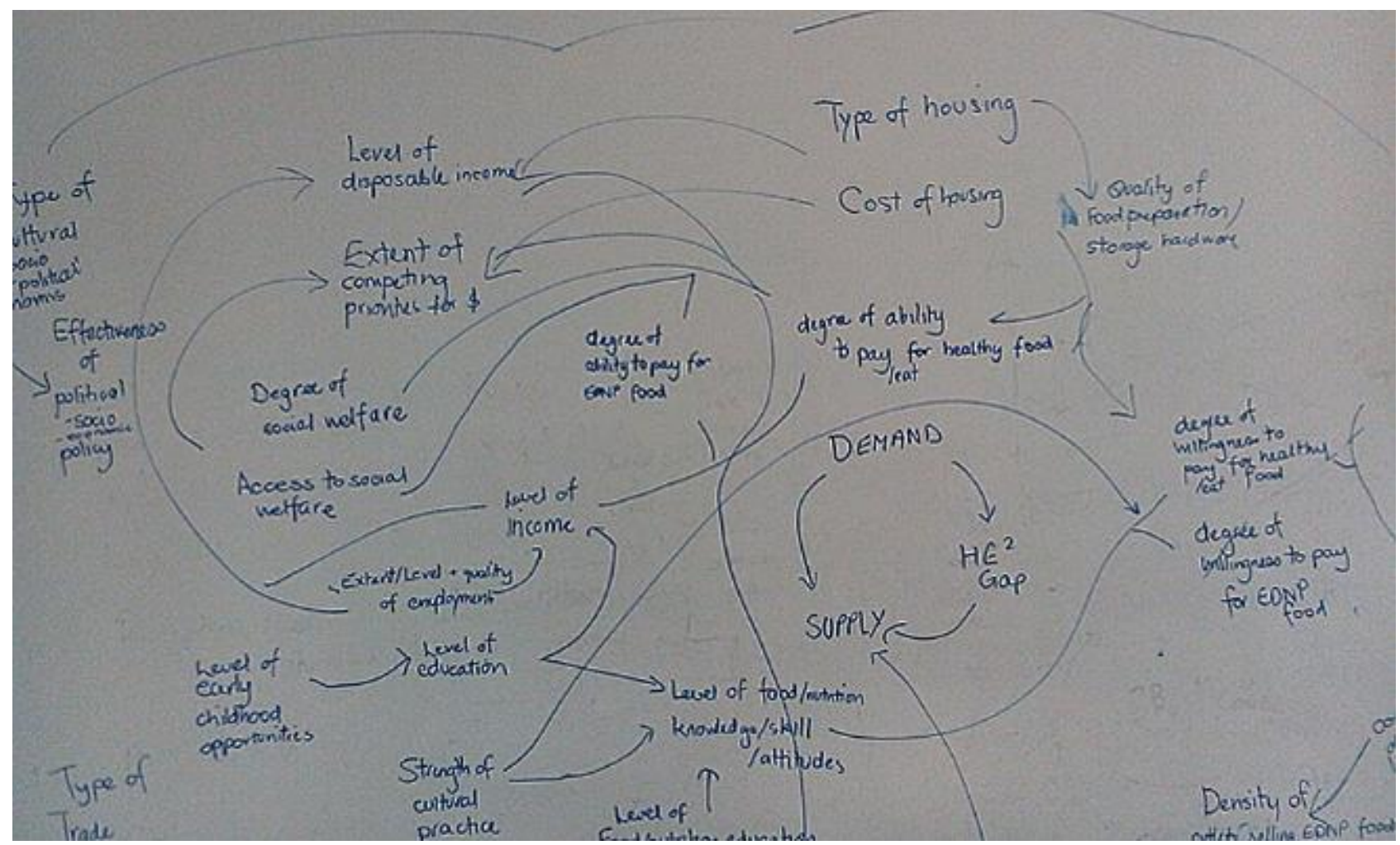

Forrás: Friel et al (2017) 


\section{A HE² oksági diagram}

A HE² diagram prezentálja az egészséges táplálkozás társadalmi egyenlőtlenségeit meghatározó tényezőket a különböző szakértők tudása és tapasztalata alapján. [2. ábra] Egy adott tényezőnek a változása olyan kapcsolódási sorozatot válthat ki, amelyek az eredeti változók esetében vagy erősítést, vagy csökkenést eredményezhet.

2. ábra: Az egészséges táplálkozási egyenlötlenségek determinánsait ábrázoló oksági diagram - a különböző alrendszerek kiemelése. A pozitiv polaritást a folytonos vonal, a negatív polaritást pedig a szaggatott vonal jelöli.

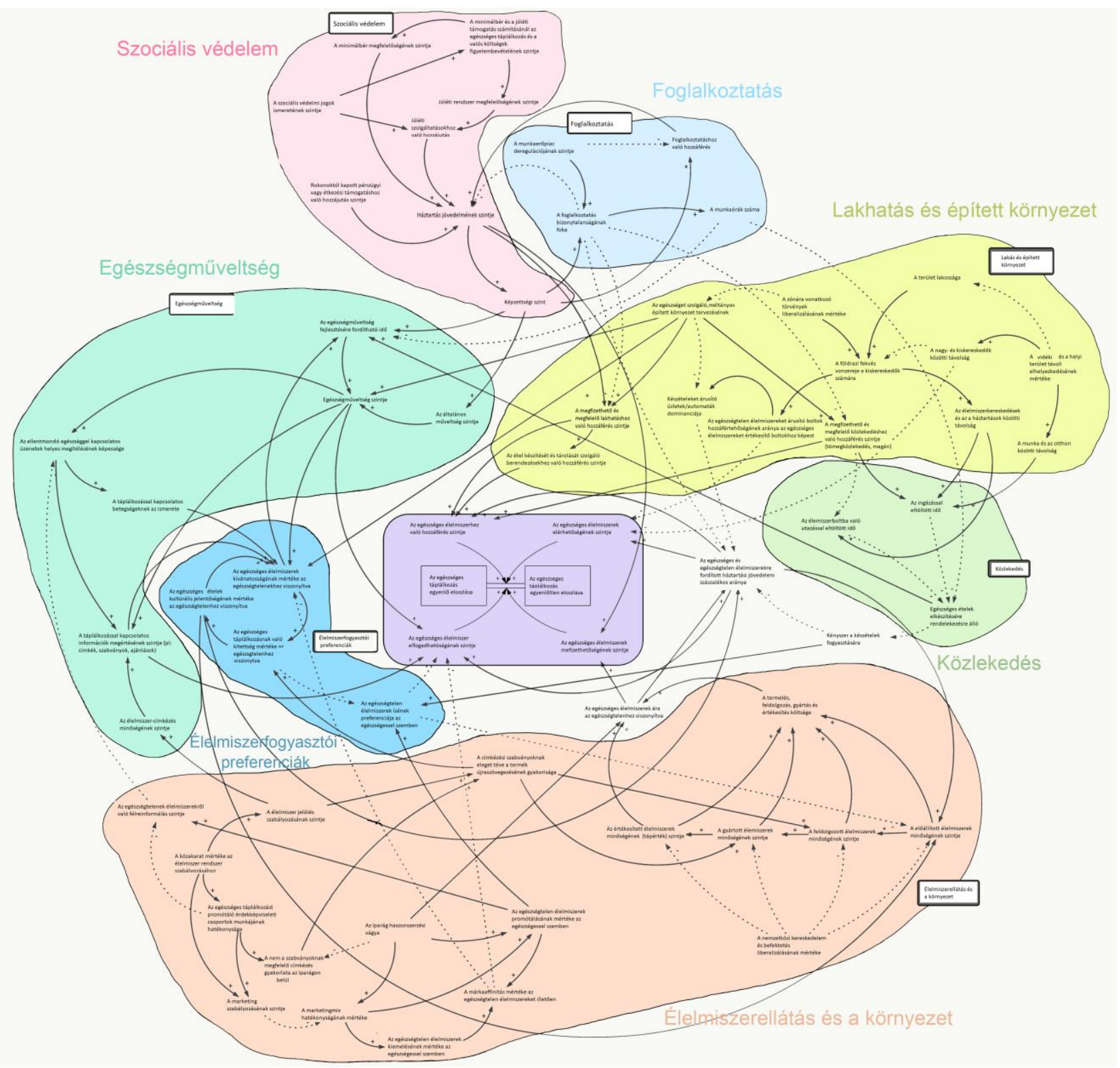

Forrás: Friel et al (2017)

Az ábra a közlemény mellékleteként is elérhető, böngészőben megnyitható és nagyítható 


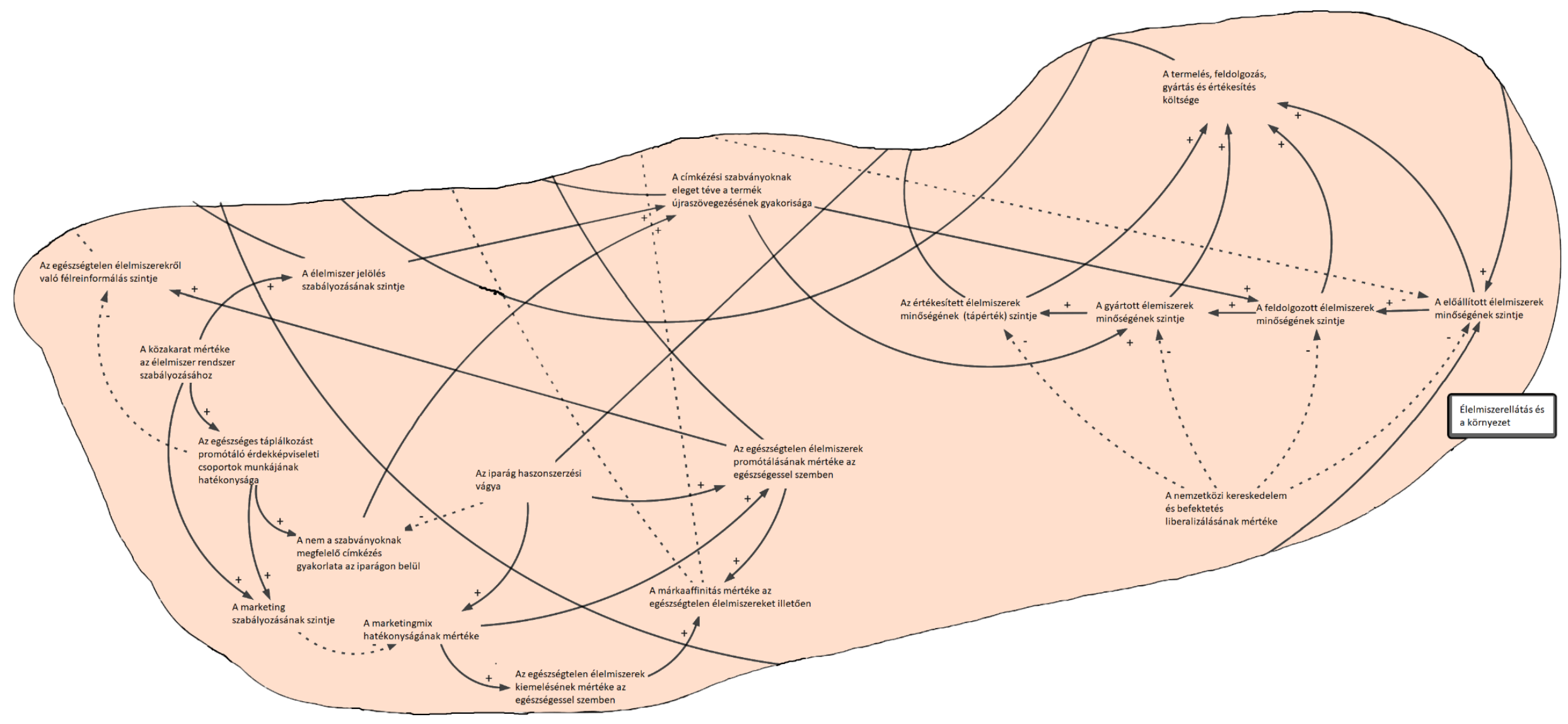

Forrás: Friel et al (2017) 


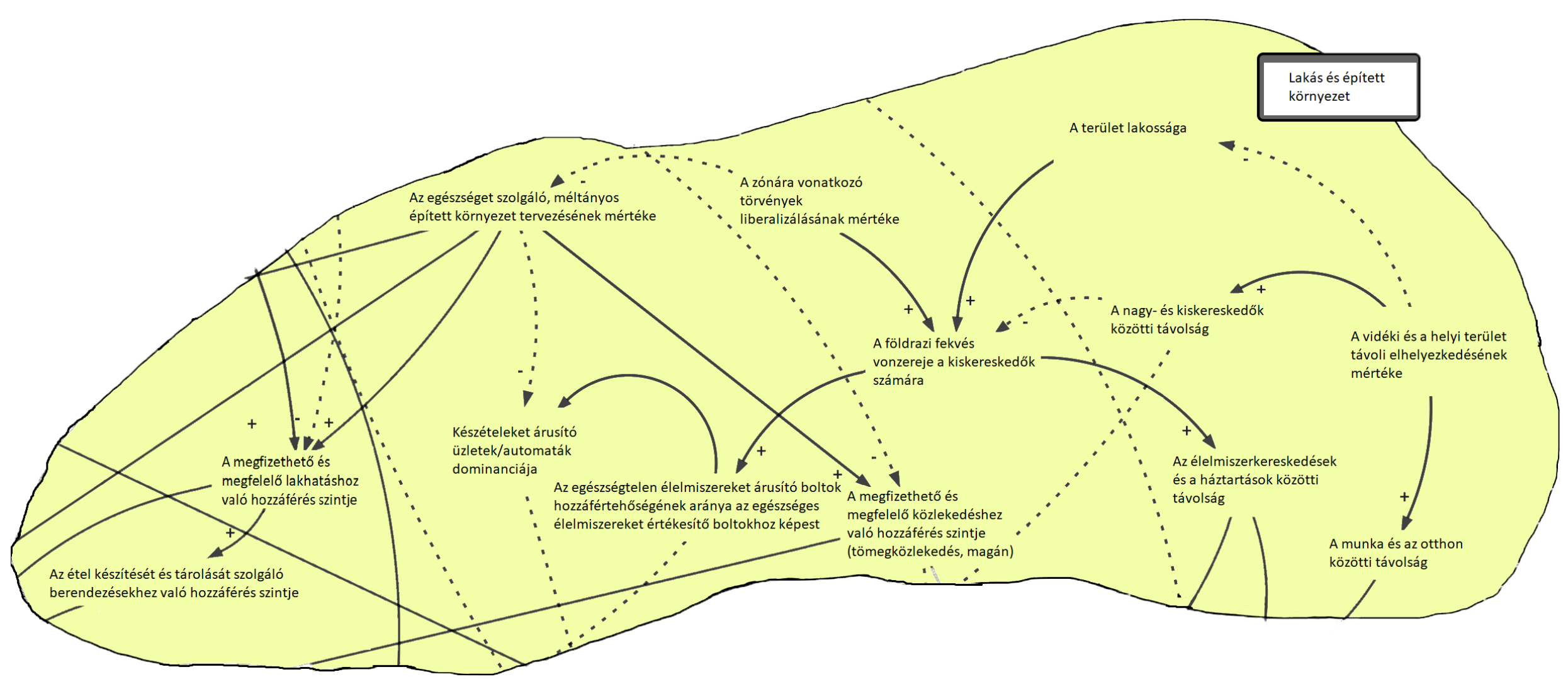

Forrás: Friel et al (2017) 


\section{A rendszer magja}

A $\mathrm{HE}^{2}$ diagram központi része a központi állomány és áramlás szakasz (stock and flow section), amelyben a két állomány az egészséges táplálkozás egyenlő és egyenlőtlen eloszlásának mértékét jelenti egy adott népesség körében. Az állomány kifejezés egy változó időbeli felhalmozódását, míg az áramlás kifejezés a változók közötti változás mértékét jelzi. A nyilak a változás mértékét jelzik, a változás mértékét pedig az egészséges élelmiszerek elfogadhatósága, megfizethetősége, hozzáférhetősége, elérhetősége befolyásolja.

\section{Az élelmiszer-ellátás és a környezet}

Ez az alrendszer mutatja be az élelmiszerminőséggel, hozzáférhetőséggel és árral kapcsolatos lépéseket az élelmiszertermeléstől a feldolgozásig, a gyártás és végül a kiskereskedelmi és élelmiszerszolgáltatási környezetben való elérhetőségig. [3. ábra] Egy visszacsatolási hurok figyelhető meg az élelmiszer címkézés és a címkézés élelmiszer átformálására és a marketingre gyakorolt hatása között.

\section{Lakhatás és épített környezet}

A lakás és épített környezet alrendszer a fizikai körülményeket foglalja magában, amelyben az emberek hozzáférnek az élelmiszerhez, és amelyben az épített környezet és lakhatás befolyásolja az élelmiszer elérhetőségét. [4. ábra] Olyan jelentős tényezőket határoztak meg a szakértők, mint például a vidéki terület, vagy egy térség nagyvárosoktól való távoli elhelyezkedése. A vidéki lokáció befolyásolja a nagy és kiskereskedők közötti távolságot, amely jelentős tényezőnek bizonyult az élelmiszerek egyenlő társadalmi eloszlását illetően Ausztráliában - számos jelentés számol be a távoli közösségekhez történő friss táplálék eljuttatásának nehézségeiről. A szakértők kiemelték, hogy az ausztrál lakosok saját otthona vagy munkahelye, illetve az egészséges élelmiszereket forgalmazó üzletek, kiskereskedők közötti távolság egy fontos tényező az egészséges élelmiszerek hozzáférhetősége szempontjából. Továbbá az épített környezet is befolyásolja a piaci körülményeket, például egy település vonzereje az élelmiszer kiskereskedések és üzletek számára. A lakásviszonyok szintén egy fontos változóként kerültek azonosításra, mivel egy minőségi lakás az egészséges táplálkozás lehetőségeit biztosíthatja azáltal, hogy megfelelőek a tárolási és az étel elkészítését biztosító feltételek. Az alacsony társadalmi-gazdasági státuszú csoportokban a lakhatási körülmények javítása csökkentené az egészségi és táplálkozási egyenlőtlenségeket.

\section{Közlekedés}

A közlekedés alrendszer az egészséges táplálkozás egyenlőtlenséginek szempontjából főként a távolságot, a munkát és az időt emeli ki. [5. ábra] Az alacsonyabb társadalmi-gazdasági helyzetben lévő csoportok körében a megfizethető közlekedésre (akár egyéni, akár tömegközlekedés) mutattak rá, amely befolyásolja az ingázással, munkába vagy egyéb helyre történő utazással eltöltött időt. Ezen tényezők mind befolyásolhatják egy egészséges étel elkészítésre vagy az egészséges táplálkozásra szánt időt, illetve azt az időt, amit az egyén egészségtudatossága fejlesztésére fordítana.

\section{Foglalkoztatás}

A munkahely szintén befolyásolja az egészséges táplálkozásban megjelenő egyenlőtlenségeket az egészséges élelmiszerek megfizethetősége miatt, amelyet nem csak az élelmiszer ára határoz meg, hanem az egyének és a háztartások jövedelme is. [6. ábra] A több múszakban végzett munka, rugalmatlan munkaidő, a túlórázás, a többszörös munkavállalás, a bizonytalan munkahely, az alacsony fizetés és alacsony munkahelyi státusz öszszefüggést mutat az otthon elkészített vagy elfogyasztott ételek számával, a rosszabb tápértékú ételekkel és az egészségtelen táplálkozással. A munkakörülmények közvetett módon is befolyásolhatják az élelmiszerválasztást azáltal, hogy hatással vannak az étkezés megtervezésére, az élelmiszervásárlásra és tervezésre szánt időre, valamint azzal, hogy hozzájárulnak a stresszhez, kimerültséghez és elégedetlenséghez. 
5. ábra: Közlekedés alrendszer

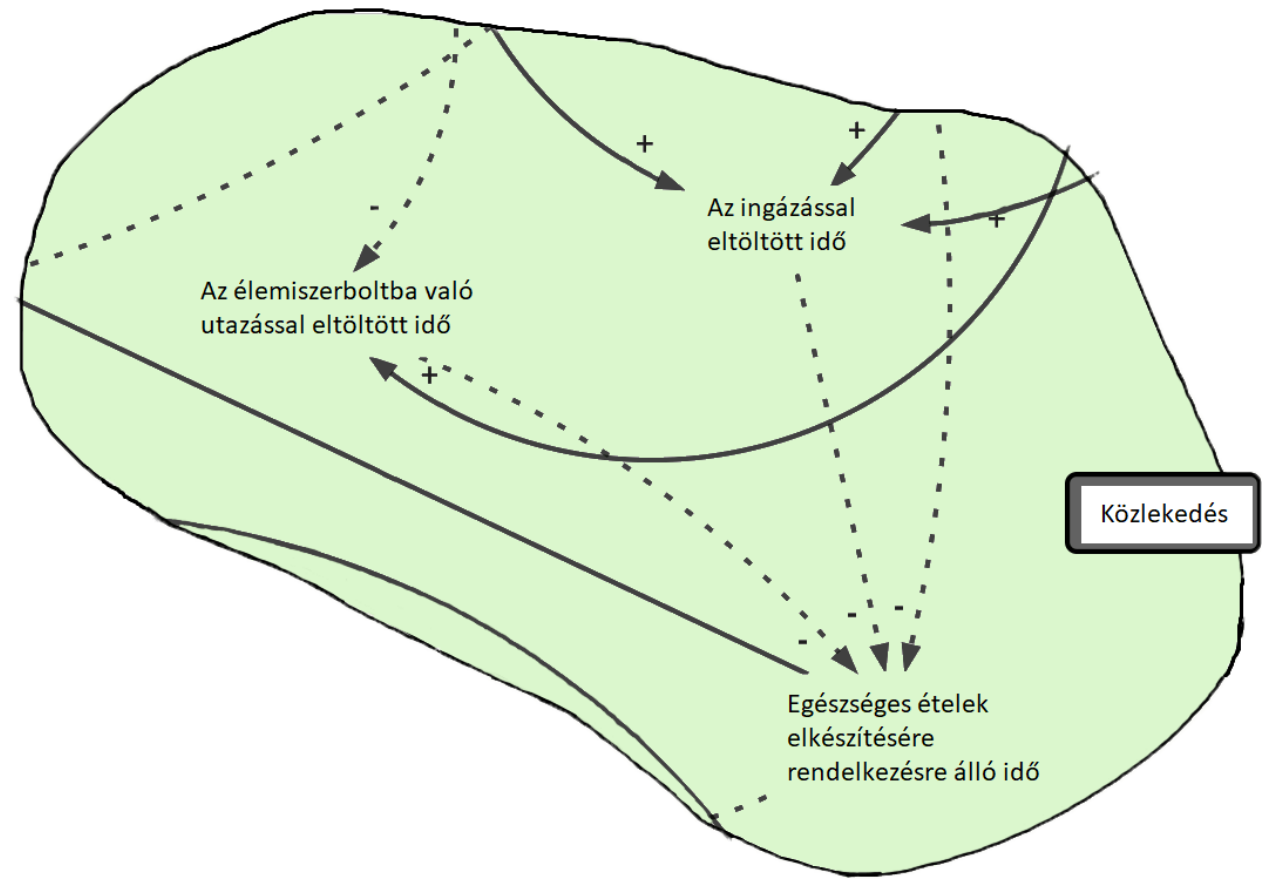

Forrás: Friel et al (2017)

6. ábra: Közlekedés alrendszer

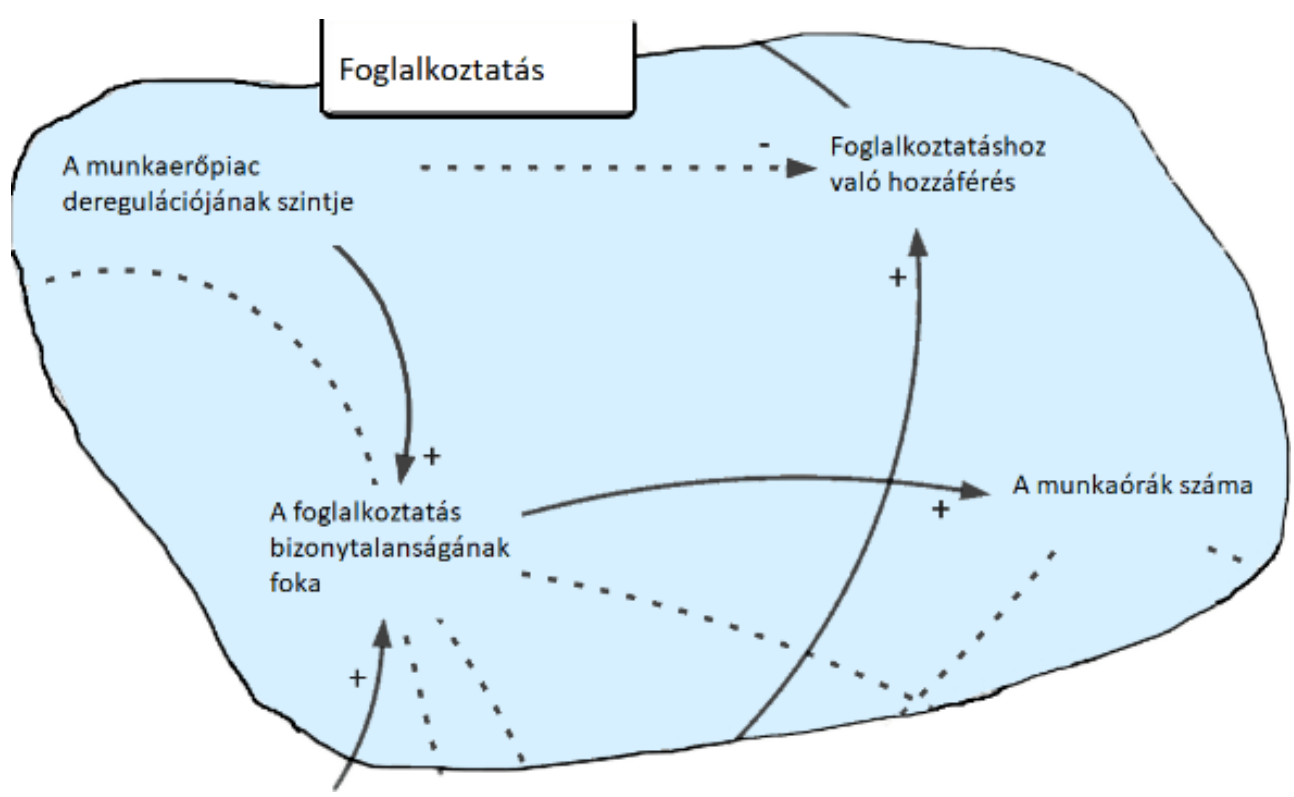

Forrás: Friel et al (2017) 


\section{Szociális védelem}

Ez az alrendszer olyan formális és informális társadalmi tényezőket foglal magában, mint az iskolai végzettség, a szociális jóléti rendszer állapota és a minimálbér, amelyek együttesen határozzák meg a háztartások jövedelmét és az egészséges ételek megfizethetőségét. [7. ábra] Az informális támogatás például rokonok vagy közösségi csoportok részéről hozzájárulhat az egészséges táplálkozáshoz, például anyagi támogatás vagy étkezés biztosításán keresztül.

\section{Egészségműveltség}

Az egészségmúveltség alrendszer magába foglalja a fogyasztó képességét a különböző egészségügyi üzenetek befogadására és a tápérték-információk megértésére, valamint hajlandóságát az egészséggel kapcsolatos ismeretei fejlesztésére. [8. ábra] A táplálkozási ismeretek hiánya egy olyan tényező volt, amely egyértelmúen az alacsonyabb társadalmi-gazdasági helyzetben lévő csoportokra jellemző.

\section{Élelmiszerfogyasztói preferencia}

Az élelmiszerfogyasztói preferenciák jelentős egyéni tényezők, melyek befolyásolják az élelmiszerválasztást. [9. ábra] A jelenlegi élelmiszerkörnyezetben a közösségek számára nehéz elkerülni a nagyon ízletes ételeket, melynek általában magas só-, cukor- és zsírtartalma van.

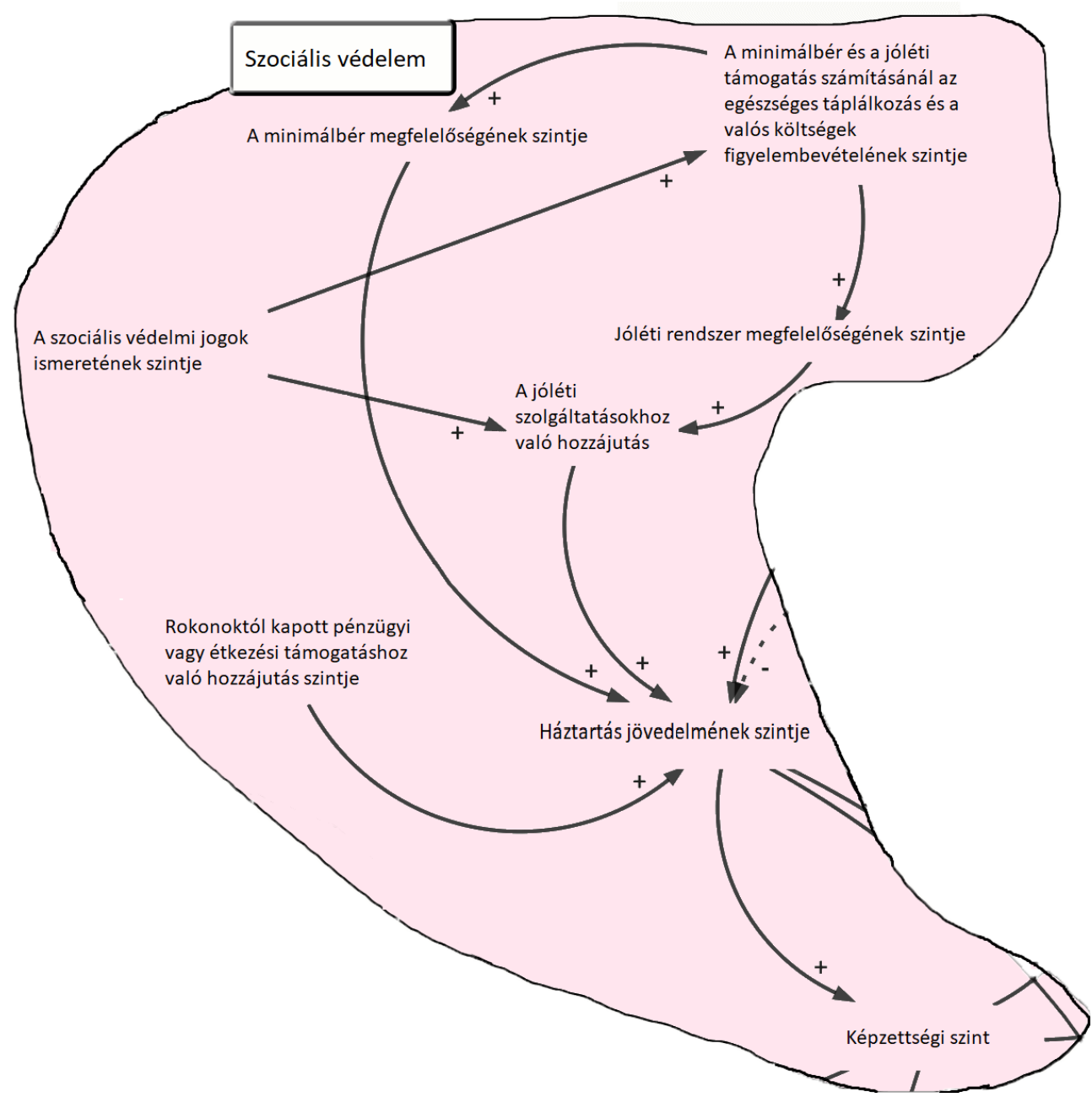

Forrás: Friel et al (2017) 


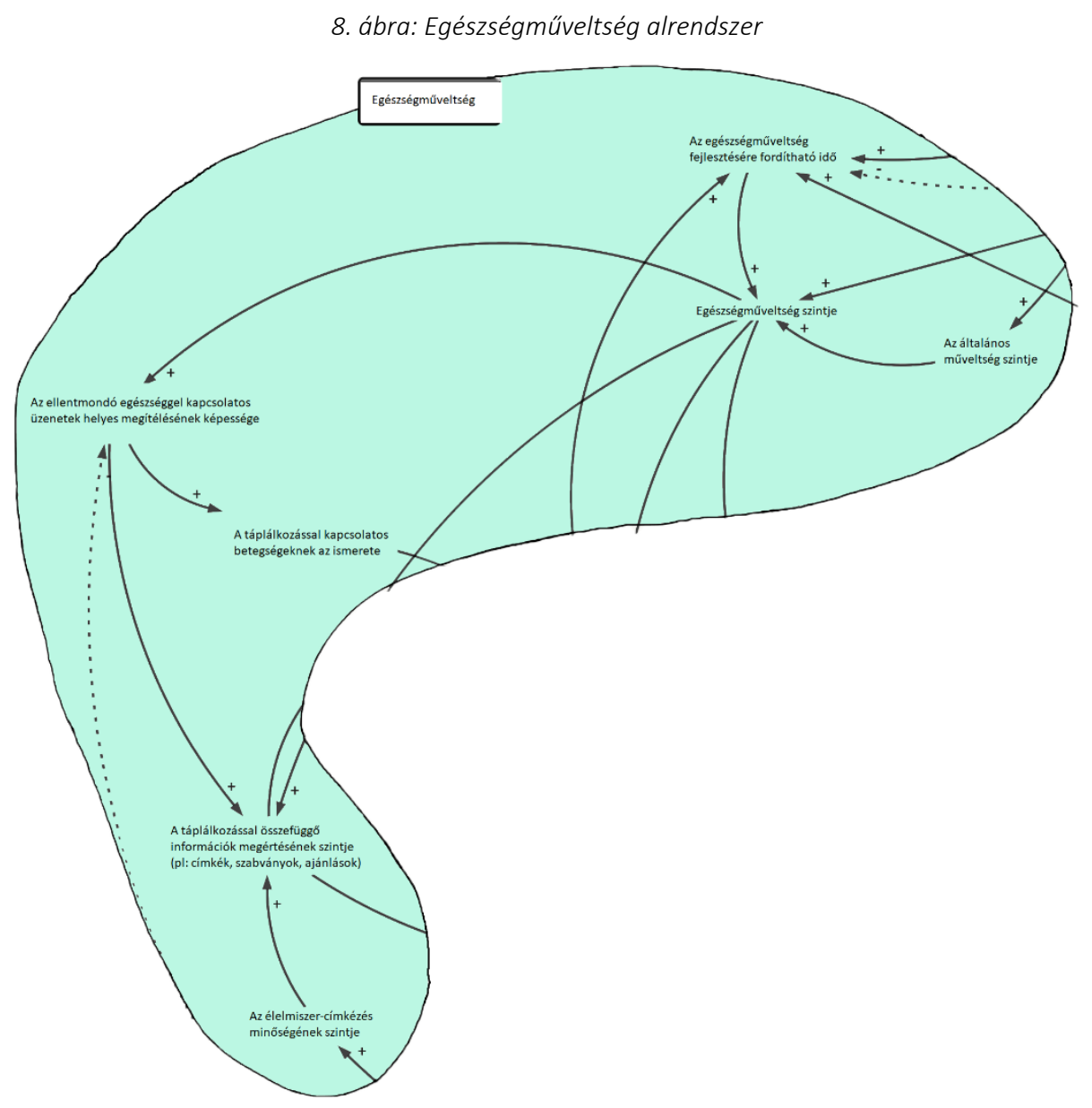

Forrás: Friel et al (2017)

9. ábra: Élelmiszerfogyasztói preferencia alrendszer

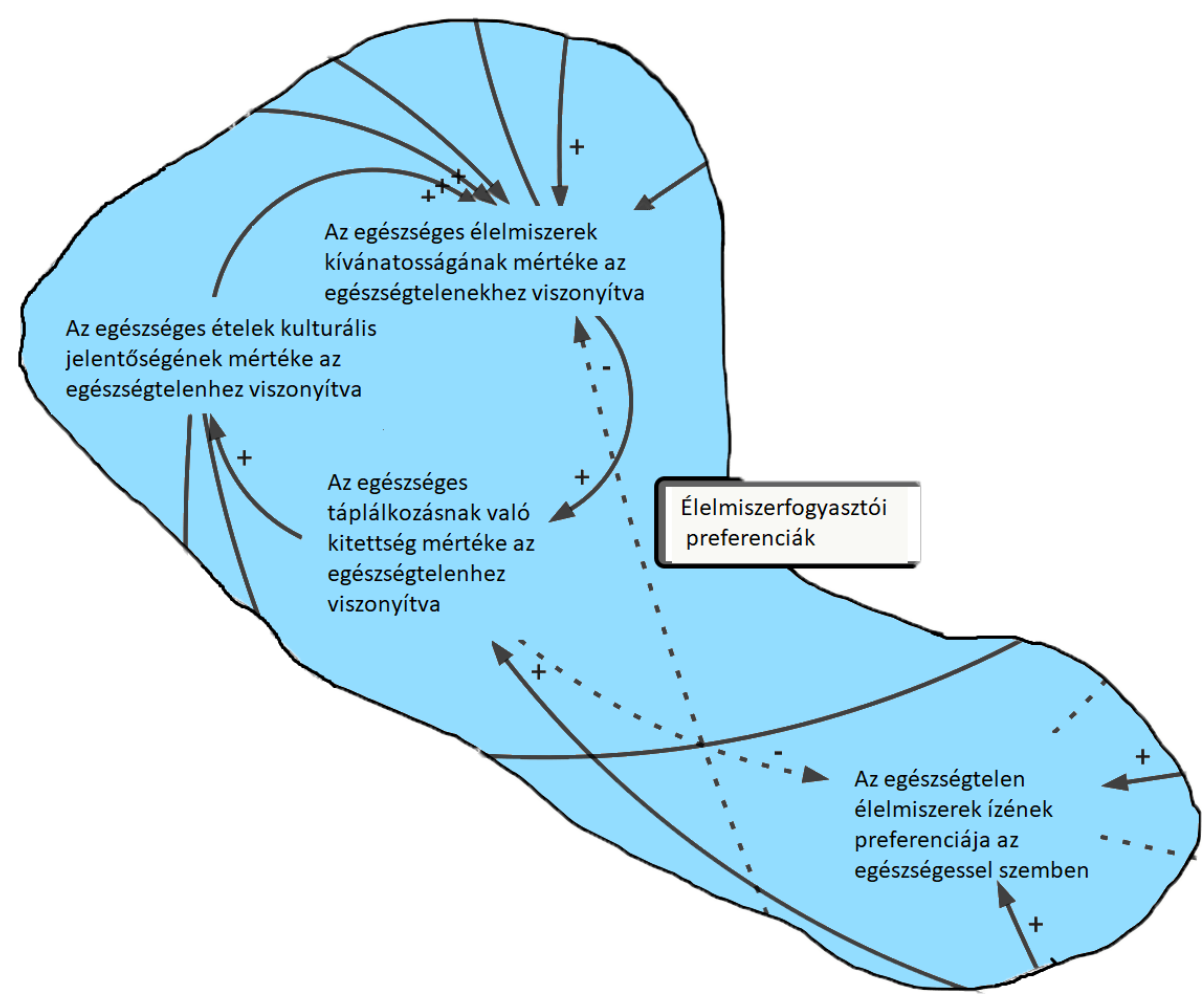

Forrás: Friel et al (2017) 
A 10. ábra a különböző alrendszerek közötti visszacsatolásokat mutatja és ezek kapcsolatát az egészséges táplálkozás egyenlőtlenségeivel.

A nyilak a magas szintű kapcsolatokat jelzik az alrendszerek között, melyek prezentálják, hogy az egészséges táplálkozás egyenlő/egyenlőtlen eloszlását hogyan befolyásolják a különböző szakpolitikai tényezők. Az ábrán látható, hogy minden egyes alrendszer befolyásolja az egészséges táplálkozás eloszlását. Megfigyelhető, hogy a „lakhatás” közvetlenül befolyásolja az egészséges táplálkozás eloszlá- sát, de más alrendszerek változóira is hatással van, mint például a közlekedésre, foglalkoztatásra, az élelmiszerellátásra és környezetre. Az ilyen visszacsatoláson alapuló alrendszerek közötti interakciók adják a $\mathrm{HE}^{2}$ rendszer összetettségét. A kereskedelem és a beruházások liberalizációja volt a legjelentősebb változó, amely befolyásolja a különböző élelmiszerek elfogadhatóságát, megfizethetőségét, hozzáférhetőségét és elérhetőségét, valamint hatással van a munkaerőpiacra és foglalkoztatásra is.

10. ábra: Az alrendszerek közötti visszacsatolás és az egészséges táplálkozás társadalmi eloszlása

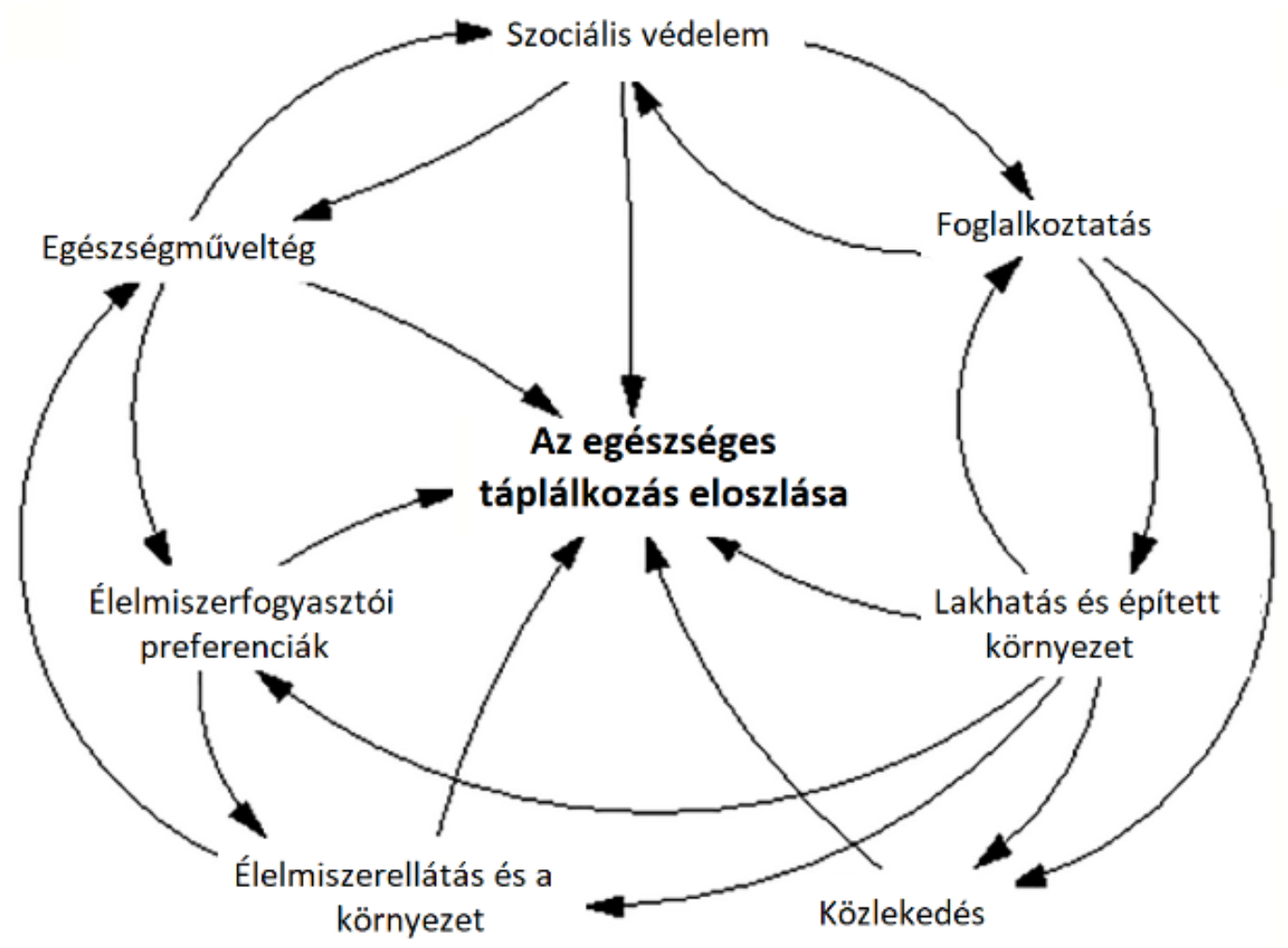

Forrás: Friel et al (2017)

\section{TANULSÁGOK A HAZAI SZAKEMBEREK SZÁMÁRA}

Jelen tanulmányban szakpolitikai szakértők bevonásával végzett rendszerszintű kutatás eredményei kerültek bemutatásra. A rendszeren belüli kapcsolatok felfedése rávilágít arra, hogy egyes ágazatokban kidolgozott és megvalósított szakpolitikák erősíthetik vagy ronthatják egy másik ágazatban végzett tevékenységeket. A tanulmány bemutatja, hogy a táplálkozásban megjelenő egyenlőtlenségek okai nem csak egyéni, hanem társadalmi szinten is rendkívül összetettek és a rendszerszemlélet alkalmazása a különböző szakpolitikai szereplők bevonásával kulcsfontosságú pontokat azonosíthat, amely hatékony és célzott beavatkozást tesz lehetővé az egészséges táplálkozás egyenlőtlenségeinek javítására. 